\title{
The Inter-American System of Human Rights and Refugee Protection: Post 11 September 2001
}

\author{
Alison Stuart* \\ Word Count - 8243
}

\section{Introduction}

The Inter-American Commission on Human Rights (Commission) is right to declare that refugees and asylum seekers are amongst the most vulnerable to human rights violations in the development and execution of counterterrorist measures. ${ }^{1}$ States have not only used their immigration laws to arrest, detain, question and deport non-nationals suspected of being involved in terrorism, ${ }^{2}$ but fear of terrorism has led states to declare a state of emergency and derogate from human rights treaties, enabling them to detain non-nationals in a manner that would normally breach their human rights.

The Commission's Report on Terrorism and Human Rights (Report) ${ }^{3}$ is an important and comprehensive document outlining the current rights of states and protections available to refugees/asylum seekers within the InterAmerican System, in relation to counter terrorism measures. While it goes into detail about a non-national's right to liberty and security, humane treatment, fair trial and due process of law, it does not discuss whether the norm of non-refoulement is derogable. The right to non-refoulement, in the 
Inter-American system, is found within article 22(8) of the American Convention of Human Rights $(\mathrm{ACHR})^{4}$. Article 22(8) states that

'In no case may an alien be deported or returned to a country, regardless of whether or not it is his country of origin, if in that country his right to life or personal freedom is in danger of being violated because of his race, nationality, religion, social status, or political opinions.'

It is a major failing of the Report that it does not take into account the fact that in a climate of terrorist attacks, states are likely to declare a state of emergency and take measures to derogate from their duties under the ACHR and the American Declaration on the Rights and Duties of Man (ADRDM). If states are able to derogate from the norm of non-refoulement, then the rights outlined in the Report are of no practical importance to a refugee/asylum seeker. The right to non-refoulement is the gateway through which a refugee/asylum seeker can access all other rights. It is therefore important to determine the extent to which states, within the Inter-American system, can derogate from the norm of non-refoulement.

While the right to non-refoulement is not specifically stated to be nonderogable within the ACHR, the Inter-American Court of Human Rights (Court) and the Commission can and should use the 1951 Refugee Convention ${ }^{5}$ and customary international law, as well as their own methods of interpretation, to prevent the principle of non-refoulement being derogable within the terms of article 27 ACHR. The 1951 Convention does not make any allowance for derogation and as such the right of non-refoulement held 
within the 1951 Convention is non-derogable. A state can not, therefore, take measures which would in effect derogate from that convention. Similarly, to the extent a norm of customary international law is based on a non-derogable right within a treaty, the norm itself is non-derogable. This means that those elements of the customary international law norm of non-refoulement that reflect non-derogable treaty rights are also non-derogable. This paper will elaborate on the following statements to support the assertion that the principle of non-refoulement is non-derogable within the Inter-American System:

- For those states that have ratified the 1951 Convention, the right to non-refoulement contained within article 33 is non-derogable, by virtue of the fact that any other interpretation would fall foul of article 27(1) and article 29 (b) ACHR;

- The customary international law right to non-refoulement is nonderogable under article 27 and article 29(d) ACHR;

- The right to non-refoulement is an integral part of each fundamental non-derogable right contained within article 27(2) ACHR and therefore non-derogable for as much as it is contained within them;

- To the extent that article 22(8) ACHR and article 27 ADRDM are essential to the full realisation of the non-derogable rights listed in article 27(2), they themselves are non-derogable. 


\section{Legal Framework Regarding Derogation within the Inter-American}

\section{System}

Most human rights treaties contain a provision allowing a state to derogate from certain rights within that treaty in a state of emergency. Article $27 \mathrm{ACHR}$ is the relevant provision that allows states to derogate not only from the ACHR, but has also been read into the ADRDM to allow states to derogate from that instrument as well ${ }^{6}$. Article 27 sets out a strict criteria that a state has to fulfil in order to be entitled to derogate. The Commission has stated that states have to satisfy the following test in order to derogate within the meaning of article 27:

'The ability of states to take measures derogating from protections under the human rights instruments to which they are bound is strictly governed by several conditions, which are in turn broadly regulated by the generally recognized principles of proportionality, necessity and non-discrimination.

In order to consider that there is an emergency justifying suspension of rights, there must be an extremely grave situation of such a nature that there is a real threat to law and order or the security of the state, including an armed conflict, public danger, or other emergency that imperils the public order or security of a member state.

Any suspension may only be for such time as is strictly required by the exigencies of the situation and may not be proclaimed for indefinite or prolonged periods.

Any suspension may only be effectuated to the extent strictly required by the exigencies of the situation, and thereby precludes the unnecessary suspension of rights, the imposition of restrictions more severe than necessary, or the unnecessary extension of suspension to regions or areas not affected by the emergency.

Any suspension of rights cannot entail discrimination of any kind on such grounds as race, color, sex, language, religion or social origin. Any suspension must be compatible with all of a member state's other obligations under international law. ${ }^{7}$

Article 27(2) also provides further limitations to a state's ability to derogate by asserting that certain rights can never be derogated from, including the right 
to life and humane treatment. Although the Commission has stated that article 27(2) ACHR enumerates all of the rights that may not be the subject of derogation, it should be noted that article $27(1)$ requires that any suspension of guarantees must not be 'inconsistent with that state's other obligations under international law'.

\section{The Right of Non-Refoulement contained within International Instruments}

The right of non-refoulement is the cornerstone of international refugee protection. In terms of the 1951 Convention, it prevents the return of a refugee to a state where her life or freedom would be threatened on account of her race, religion, nationality, membership of a particular social group or political opinion. In human rights law, it applies to prevent a state returning an individual to a place where there is a real risk her fundamental human rights would be violated.

The 1951 Convention makes no provision for derogations. Its provisions are non derogable, including the right of non-refoulement. Although the right of non-refoulement is non-derogable, it is, however, subject to certain limitations within the 1951 Convention. Only refugees have the right not to be returned and the definition of 'refugee' is itself restricted by the application of article 1F of the 1951 Convention. Article 1F excludes those who would otherwise be refugees, from refugee status, on the grounds that there are serious reasons for considering that they have committed a crime against humanity, a serious 
non-political crime outside the country of refuge prior to admission, or acts contrary to the purposes and principles of the UN. Another limitation is held within the non-refoulement article itself. Article 33(2) denies the benefit of non-refoulement to 'a refugee whom there are reasonable grounds for regarding as a danger to the security of the country in which he is, or who, having been convicted by a final judgement of a particularly serious crime, constitutes a danger to the community of that country'. It can be seen that this could lead to those suspected of committing or having the intent to commit terrorist crimes being returned to states where their life or freedom is in danger. These limitations have the potential to reduce dramatically the protection given by non-refoulement. They also leave the process open to discrimination as countries increasingly target specific nationalities and religions as breeding ground for potential terrorists and reduce the quality of proof needed to make a 'dangerous to the security of the country' determination.

Human rights instruments, while in the main allowing for some derogation, do not have the limitations inherent in the refugee law concept of nonrefoulement. The protection given by article 22(8) ACHR has no equivalent to article $1 \mathrm{~F}$ or $33(2)$. It does not allow anyone to be returned to a country where their right to life or freedom would be threatened on account of their race, religion, nationality, membership of a particular social group or political opinion regardless of whether they are a refugee or constitute a danger to society. Article 3, Convention against Torture and Other Cruel, Inhuman or Degrading Treatment or Punishment $1984(\text { CAT })^{8}$ is similarly absolute in its 
terms and prevents an individual being returned to a state where there are substantial grounds for believing that they would be in danger of being tortured. While on the face of it article 22 ACHR is derogable, article 3 CAT is not.

There are also an increasing number of 'soft law' instruments prohibiting nonrefoulement in regard to specific violations. The UN Declaration on the Protection of All Persons from Enforced Disappearances1992 prevents expulsion, return or extradition where there are substantial grounds to believe a person would be in danger of enforced disappearance. The UN principles on the Effective Prevention and Investigation of Extra-Legal, Arbitrary and Summary Executions, prevent the same in relation to extra-legal, arbitrary and summary executions. These instruments, while not per se legally binding, are indications of growing opinio juris on the norm of nonrefoulement. Further, the Court has stated that

'The corpus juris of international human rights law comprises a set of international instruments of varied content and juridical effects (treaties, conventions, resolutions and declarations). Its dynamic evolution has had a positive impact on international law in affirming and building up the latter's faculty for regulating relations between States and the human beings within their respective jurisdictions. This Court, therefore, must adopt the proper approach to consider this question in the context of the evolution of the fundamental rights of the human person in contemporary international law."

Both the Court and the Commission could therefore determine that the above declarations form part of the corpus juris of international human rights law and use them to shape their interpretation of the relevant sections within 
ACHR/ADRDM and their determination of the customary law content of the norm of non-refoulement.

\section{The Customary International Law Principle of Non-Refoulement within the Inter-American System}

It is clear that in the past the content of the customary international law principle of non-refoulement, in a refugee law context, was based primarily upon article 33 of the 1951 Convention. While this is still the case today, it could also be argued that the principle has now extended beyond the parameters of article 33 to protect those displaced persons who do not enjoy the protection of their government and are seen to be humanitarian 'refugees'. Until recently there was controversy over whether states have a legal duty under customary international law not to return humanitarian refugees to their state of origin. In customary law terms, the existence of such a legal duty depends first on whether states have refrained from returning such persons to their state of origin and, secondly, whether they did so in the belief that they are legally obliged to temporarily protect/non-refoule such persons. The problem in declaring whether such a norm had evolved came not from a lack of state practice ${ }^{10}$, but whether there was sufficient opinio juris at a universal level to conclude that such a norm of customary international law has been created. However, as Lauterpacht and Bethlehem make clear ${ }^{11}$, it is now undeniable that the principle of non-refoulement reflects customary international law. Moreover, this problem is largely resolved in the Inter-American context by additional evidence that a regional 
customary norm of non-refoulement of humanitarian refugees has crystallised. The 1984 Cartagena Declaration and previous state adherence to it would suggest that OAS states have accepted they have a legal duty not to refoule humanitarian refugees.

The 1984 Cartagena Declaration was drafted in response to mass migration and instability within the Americas in the 1980s. Its drafting was part of a plan to bring peace and stability to the region and, to that end, the Declaration incorporated a realistic refugee definition. The definition includes those fleeing 'widespread violence, foreign aggression, internal conflicts, massive violations of human rights, or other circumstances which have seriously disturbed public order ${ }^{12}$ as well as those that come within the traditional 1951 Convention definition. This widened definition is almost identical to the refugee definition within the OAU Convention, reflects those persons protected by UNHCR and includes those referred to as refugees by the Commission in its reports. There have been several resolutions by the General Assembly of the OAS re-iterating the importance of the Cartagena Declaration ${ }^{13}$ and calls from the UNHCR and the Commission for states to adhere to it.

In the years immediately preceding the drafting of the Cartagena Declaration, a number of OAS states incorporated the expanded refugee definition into their domestic refugee/asylum laws and that practice continues. Currently, eight ${ }^{14}$ out of the thirty-five member states of the OAS have incorporated the expanded definition within their domestic laws, while others appear simply to 
apply it in practice. Paradoxically it appears that although some states have incorporated the expanded definition within their domestic laws, in practice they do not apply it. In more recent years, there seems to have been a move away from the actual application of the expanded definition. It is questionable, however, whether this shift in practice is sufficient to displace the presumption that the norm of non-refoulement in the Americas includes the right of everybody not to be returned to a state where their life or freedom would be in danger. This is particularly the case where it appears that more and more human rights bodies are widening the principle of non-refoulement in relation to fundamental human rights.

The human rights law content of the customary norm of non-refoulement quite clearly includes the right of an individual not to be returned to a country where he would be subject to torture or cruel, inhuman or degrading treatment or punishment. Although neither the Commission nor the Court have had an opportunity to rule on the matter, the practice of other human rights bodies could provide useful guidance. It is quite obvious from statements of the Commission, the jurisprudence of the European Court of Human Rights ${ }^{15}$ and the Human Rights Committee (HRC) $)^{16}$ that they consider the right of nonrefoulement an integral part of the prohibition of torture. As the European Court of Human Rights stated in Soering $v U K^{17}$

'It would hardly be compatible with the underlying values of the Convention, that "common heritage of political traditions, ideals, freedom and the rule of law" to which the Preamble refers, were a Contracting State knowingly to surrender a fugitive to another State where there were substantial grounds for believing that he would be in danger of being subjected to torture, however heinous the crime allegedly committed. 
Extradition in such circumstances, while not explicitly referred to in the brief and general wording of Article 3 (art. 3), would plainly be contrary to the spirit and intendment of the Article, and in the Court's view this inherent obligation not to extradite also extends to cases in which the fugitive would be faced in the receiving State by a real risk of exposure to inhuman or degrading treatment or punishment proscribed by that Article (art. 3).'

From the jurisprudence outlined above, it can be deduced that the reason that non-refoulement is disallowed in relation to a person where there are substantial reasons for believing he would be subject to torture on his return, is because the prohibition of torture is a fundamental non-derogable norm. It follows that insofar as a right or prohibition is a fundamental norm, the corresponding right not to refoule someone when they would be in real danger of one of these norms being violated is similarly non-derogable. The obligation of a state to respect the fundamental rights of an individual, such as to life, liberty and personal integrity, limits its ability to act where this would place the individual at risk. Strict adherence to the principle of non-return is one way that such basic rights can be ensured. Therefore, the content of the human rights law element of the customary international law right of nonrefoulement includes the right not to be returned where any of an individual's fundamental human right norms would be violated.

While the refugee law element of the customary norm of non-refoulement is subject to the limitations contained within article $1 \mathrm{~F}$ and article 33(2) of the 1951 Convention, the human rights law element of the customary right of nonrefoulement is an absolute right and not subject to any limitations regardless of whether a person is suspected of any involvement in terrorist acts ${ }^{18}$. 


\section{The Application of International Human Rights Instruments within the Inter-American System}

The Court and Commission can only apply the 1951 Convention or any other international agreement indirectly by using them as an aid to interpreting the Inter-American human rights instruments over which they have jurisdiction to 'adjudicate'19. There is no complaints mechanism set out within the 1951 Convention. A dispute regarding the interpretation or application of the 1951 Convention may be brought before the International Court of Justice by a state party. In real terms, however, the 1951 Convention does not provide for the enforcement of its terms. Although the Court and Commission cannot directly apply the 1951 Convention, it can be indirectly applied through the appropriate articles in the ACHR and the ADRDM. The Commission has declared that the guarantees in article 22(7) ACHR and article 27 ADRDM reflect those contained within the 1951 Convention $^{20}$ and has used the 1951 Convention to develop the detailed content of the above articles in all cases involving refugee/asylum rights before it.

The Commission has become increasingly proactive in fleshing out refugees and asylum seekers' rights once they are admitted into a state. It has, however, tended to concentrate on strengthening the procedural safeguards in place, as opposed to actually preventing the non-refoulement of individuals in violation of article 22(7) and (8) ACHR and article 27 ADRDM. This stance is understandable in relation to their reluctance to be a 'fourth instance,21 court. However domestic adjudicating bodies within the region need more 
guidance from the Court and Commission in interpreting the actual substantive content of the above articles.

Although both the ACHR and the ADRDM contain the right to seek and receive asylum, the right of non-refoulement is only specifically spelled out in article 22 (8) ACHR. This distinction could prove problematic if an OAS state has ratified neither the ACHR nor the 1951 Convention. Article 27 ADRDM is subject to a dual criterion: the right to seek and receive asylum can only be relied upon if and to the extent that it has been spelled out in domestic law and the relevant international agreements have been ratified. This dual criterion could result in a situation whereby a state that has not enshrined the right to asylum within its domestic legal system or ratified the 1951 Convention, is not bound by article 27 ADRDM.

While the Commission has declared that the 1951 Convention is the relevant international agreement in relation to asylum ${ }^{22}$, it is unclear whether a state must have ratified the 1951 Convention for it to be applicable. As the Commission has accepted that the 1951 Convention forms 'part of developments in the corpus of international human rights law more broadly that are properly taken into account in evaluating states' human rights obligations in the Inter-American system ${ }^{23}$, it could apply the Convention regardless of whether a state has ratified it. The right of non-refoulement within article 27 ADRDM encapsulates that held within article 33 of the 1951 Convention, however, and is therefore subject to its limitations. That is not to 
say though that the 1951 Convention is the only international instrument relevant to article 27 ADRDM; article 3 of CAT could also be applicable.

\subsection{Non -Derogability of International Agreements within the ACHR and the ADRDM}

Article 27(1) ACHR requires that any measures a state takes derogating from its obligations under the convention may not be 'inconsistent with that state's other obligations under international law'. The Commission has expressly stated that this prevents states from circumventing their obligations under other conventions. In Abella, it declared that

\footnotetext{
'If [the Commission] finds that the rights in question are not subject to suspension under these humanitarian law instruments, the Commission should conclude that these derogation measures are in violation of the State Parties obligations under both the American Convention and the humanitarian law treaties concerned. ${ }^{24}$
}

This means that where a state has ratified the 1951 Convention and/or CAT, it cannot apply derogation measures that would violate its obligations under them by virtue of article 27(1) ACHR. Additionally, as both instruments are 'conventions to which the state is a party', article 27 could not be interpreted in a way, which would restrict any rights or freedoms established under either convention by operation of article 29(b) ACHR.

The 1951 Convention and CAT are non-derogable in their entirety, therefore, where a state has ratified the 1951 Convention and/or CAT it may not take any measures which would have the effect of negating an obligation held 
within either convention and, specifically, article 33 of the 1951 Convention and article 3 CAT. If a state did take such measures, the Court and/or the Commission would have jurisdiction to rule on the matter as a violation of article $27 \mathrm{ACHR}$. It is logical to conclude that because a state is unable to derogate from its duties under the 1951 Convention and CAT, article 22(7) and (8) ACHR and article 27 ADRDM must similarly be non-derogable in order that such rights continue to be enforceable within the Inter-American System. Any other conclusion would have the practical effect of negating the prohibition on derogation from the 1951 Convention and CAT.

\subsection{The Application of non-refoulement as Customary International Law within the Inter-American System}

The principle of non-refoulement of refugees is now widely recognised as a general principle of customary international law. Article 38(1) of the Statute of the International Court of Justice $1945^{25}$ includes 'international custom' as one of the main sources of international law and the Commission has harnessed this idea and declared that it can use customary international law as 'part of developments in the corpus of international human rights law more broadly that are properly taken into account in evaluating states' human rights obligations in the inter-American system, ${ }^{26}$. The customary norm of nonrefoulement can therefore be used to help inform the scope of the rights held within the ACHR and ADRDM, specifically article 22(7) and (8) ACHR and article 27 ADRDM. 


\subsection{Non-Derogability of the Customary International Law Norm of Non- Refoulement}

A state can only derogate from a treaty to the extent for which that is expressly allowed. The 1951 Convention does not allow for derogation, so a state cannot take measures that would in effect derogate from that convention. Where a norm of customary international law is formed from a right articulated in a convention, if that right is non-derogable within the relevant convention so, too, is the customary international law norm that reflects it. This means that those elements of the customary international law norm of non-refoulement that reflect article 33 of the 1951 Convention and article 3 CAT are, like article 33 and article 3, non-derogable. However it should be noted that this customary international law norm will also retain the limitations to the right of non-refoulement encapsulated within article $1 \mathrm{~A}(2)$ and $\mathrm{F}$ and article 33 of the 1951 Convention.

Thus norms of customary international law are part of a state's 'obligations under international law' and any measures a state takes under article 27 cannot be inconsistent with them. A state cannot therefore take any measure that would violate its duty not to refoule under customary international law. The Commission has expressly stated that article 27(1) prevents states from circumventing their other obligations under both conventional law and customary international law. A fact illustrated by the Commission's conclusions in Abella, where it affirmed that it will review the legality of a state's derogation measures not only by reference to the text of article 27 
$\mathrm{ACHR}$, but also by whether the measures violated any non-derogable rights within humanitarian law. The Commission specifically included customary humanitarian law within this category. Clearly if this principle is applied to refugee law, a state cannot take derogation measures that would violate its obligations under the customary international law norm of non-refoulement.

Where a state may accept that it cannot derogate from its obligations under the 1951 Convention and CAT, it may not so easily accept that it cannot take derogation measures which violate customary international law. There has not been an international case on this point, but certain statements of the HRC in its General Comment $29^{27}$ would seem to suggest that although article 4 ICCPR stipulates that such derogation measures should not be 'inconsistent with its other obligations under international law'28, the HRC feels that only the fundamental norms of international law, as opposed to customary international law in its entirety, are non-derogable. Of course a derogation clause is only applicable to the treaty it forms a part of. However where norms of customary international law are derived from rights that are non-derogable within the relevant treaties, those norms of customary international law are similarly non-derogable.

The customary international law element of non-refoulement is also nonderogable under both the ACHR and ADRDM because of the fact that denial of such a norm would put at risk the majority of rights listed as non-derogable by article 27 (2) ACHR. In particular, those rights within Article 3 (Right to Juridical Personality), Article 4 (Right to Life), Article 5 (Right to Humane 
Treatment), Article 9 (Freedom from Ex Post Facto Laws), Article 12 (Freedom of Conscience and Religion), Article 17 (Rights of the Family), Article 19 (Rights of the Child) and Article 23 (Right to Participate in Government). The right to non-refoulement is specifically designed to prevent people being returned to states where their right to life or freedom would be threatened on account of their race, religion, nationality, membership of a particular social group or political opinion. Clearly if the right of nonrefoulement is not adhered to, a person could be returned to a state where their right to life, right to humane treatment, right to religion, right to participate in government or freedom from ex post facto laws is at risk. Less obviously a person's right to juridical personality, family and the rights of the child are at risk. A person who is unable to legally challenge their return to an 'unsafe' state by operation of the denial of the norm of non-refoulement is in effect denied the right to a juridical personality in the state that refouled him.

Without necessarily accepting that non-refoulement is a peremptory norm of international law, the Executive Committee of UNHCR has been suggesting that the refugee law principle of non-refoulement amounts to a rule of jus cogens from as early as 1982. In the Inter-American system, the 1984 Cartagena Declaration stated 20 years ago that the principle of nonrefoulement 'should be recognized and respected in the present state of international law, as a principle of jus cogens'. Neither the Executive Committee conclusions nor the 1984 Cartagena Declaration have the force of law or create any binding legal obligations, but they are persuasive. The fact that OAS member states have accepted that the norm of non-refoulement is 
jus cogens is given weight by continual OAS General Assembly resolutions encouraging states to ratify the 1951 Convention, acknowledging the Cartagena Declaration with approval and exhorting OAS states to incorporate its findings within their nationals laws. If the right to non-refoulement is accepted as a peremptory norm, then it would clearly be non-derogable.

While the scope of the jus cogens element of the refugee law norm of nonrefoulement is mapped out by the definition of 'refugee' and article 33 of the 1951 Convention, the status of the human rights element of the norm relies on the consequences of its violation. If freedom from torture is a peremptory norm of international law, then is accepted that the non-return of an individual to a state where they would be tortured is also a peremptory norm. In essence it is not so much that the human rights norm of non-refoulement is in and of itself peremptory, but the violation that it prevents is. A state may not therefore refoule an individual where any of these peremptory norms are in danger of being violated. The logical conclusion to draw is that the norm of non-refoulement is an integral part of those fundamental values that are already international peremptory norms.

\subsection{Non -Derogability of the Human Rights Law Norm of Non- Refoulement}

It is suggested that the human rights element of non-refoulement is located within the content of each fundamental non-derogable right. The practice of the European Court of Human Rights points to some new developments in 
this area that could help inform the scope of the right of non-refoulement within the Inter-American system. The European Court of Human Rights has developed a precedent of placing certain 'procedural' rights directly within the articles relating to fundamental non-derogable rights. In Kilic v Turkey, the European Court of Human Rights held that the sentence 'Everyone's right to life shall be protected by law ${ }^{29}$ within article $2 \mathrm{ECHR}$, enjoins a state to take appropriate steps to safeguard the lives of those within its jurisdiction. In this case the European Court of Human Rights felt that the appropriate steps were the putting in place of effective criminal law provisions and the like to deter the commission of offences against the person. The appropriate steps do, however, vary depending on the circumstances of each case. In the situation where a person is being returned to a state where they are danger of being tortured, insistence on non-refoulement is the obvious and appropriate step.

In Soering $v$ U.K., The European Court of Human Rights implicitly brought the right of non-refoulement within article 3 , and has continued to apply that principle in later cases. The European Court of Human Rights accepted that permitting refoulement in such circumstances would make inroads in the nonderogability of the prohibition of torture. The HRC has also recognised this. The HRC explicitly stated within its General Comment $20^{30}$ that States parties must not expose individuals to the danger of torture or cruel, inhuman or degrading treatment or punishment upon return to another country by way of their extradition, expulsion or refoulement. It has further adopted this view in 
its examination of individual petitions ${ }^{31}$. In its recent General Comment 31, the HRC specifically stated that

\begin{abstract}
'the article 2 obligation requiring that States Parties respect and ensure the Covenant rights for all persons in their territory and all persons under their control entails an obligation not to extradite, deport, expel or otherwise remove a person from their territory, where there are substantial grounds for believing that there is a real risk of irreparable harm, such as that contemplated by articles 6 and 7 of the Covenant, either in the country to which removal is to be effected or in any country to which the person may subsequently be removed ${ }^{32}$
\end{abstract}

The right to non-refoulement is not just an inherent part of the prohibition on the use of torture however, but is also an integral part of all fundamental nonderogable rights within ADRDM and ACHR.

The Commission has already found, in the Haitian Centre for Human Rights case $^{33}$, that a state breaches the right to life within article 1 ADRDM, where it repatriates refugees who later lose their lives due to being identified as 'repatriates' within their country of origin. It further held that a state breaches a person's right to security within article 1 ADRDM, where it repatriates refugees who were as a result later exposed to acts of brutality by the returning state's military and supporters. Although in this case the Commission only found a breach of article 1 ARDRM in cases of actual violation, it appeared to have based its findings on existing international case law on extradition. It is quite clear in existing jurisprudence that where a state takes a decision concerning a person within its jurisdiction and the necessary and foreseeable consequence is that that person's rights under the relevant international instrument are violated within another jurisdiction, the state that 
returned that person, in whatever way, has itself violated its duties under the relevant international instrument. This approach opens the door for the Commission to declare in the future that a state cannot refoule where there is a potential, as opposed to an actual, violation of a person's fundamental human right in question.

\subsection{Difference in Burden of Proof}

The difference between the refugee law norm of non-refoulement and the human rights norm of non-refoulement lies not just in the limitations and question of derogability, but also in the standard of proof required by each. In refugee status determinations the standard of proof is usually whether there is a reasonable degree of likelihood ${ }^{34}$ that the individual would be persecuted/have their life or freedom threatened. This is a lower standard of proof than that required under human rights law. As stated above, the standard of proof applicable to engage a state's responsibility for a violation that occurred due to them returning an individual to another state under human rights law is whether there was a 'real risk' that, that individual would be subjected to the violation. Although neither the Court nor the Commission have addressed this issue, both the HRC and the European Court of Human Rights have used this idea of a 'real risk' to inform their decisions in the past. It is submitted that it is likely that the Inter-American system would use a similar standard of proof. It should be noted, however, that there are differences in the way the European Court of Human Rights and the HRC 
have applied the test, with the European Court of Human Rights appearing to have applied the test less restrictively than the HRC.

In Mrs G.T. v Australia, the 'real risk' test was framed in such a way that proof of the receiving state's actual intention to violate the individual's fundamental rights appeared to be required before the right not to be returned could be invoked. This is a very high standard of proof and one that is almost impossible for the individual to fulfil in most cases. It should be noted in this regard that the only time the $\mathrm{HRC}$ has found the "necessary and foreseeable consequence' test fulfilled is in cases of extradition, where the intent of the state to violate a fundamental human right was inescapable. The European Court of Human Rights has been more forgiving and in Chahal v. UK looked at the general threat of human rights violations to persons within the same group as the petitioner to determine whether that individual was under a real risk of an article 3 violation if refouled as opposed to whether there was proof of the receiving state's intent to torture that particular individual ${ }^{35}$. Neither the Court nor the Commission have so far given a decision on the merits preventing a state from returning individuals where there was a real risk that such individuals would be in danger of their rights being violated in the receiving country. The Commission has, however, already used a similar test to the one used by the European Court of Human Rights and the HRC in a non-refoulement case ${ }^{36}$ and would probably use the same test in any future non-refoulement issues before it. 
This high standard of proof could lead to a situation where a person, who would be entitled to the protection of article 33 but for the operation of article $1 \mathrm{~F}$ or article 33(2), would fail to be protected from non-refoulement in human rights law. So far all the cases regarding the human rights element of the norm of non-refoulement have related to those who have an individualised claim of a violation of fundamental rights, that is, those who would be singled out from the rest of the population. Although it could be argued that the applicant in Chahal v. Austria received protection solely due to the fact of clan warfare in Somalia and not in relation to any individualised claim, it was stressed in this judgement that not only had the applicant been involved in the activities of the opposition group but the respondent state had tself accepted that the applicant was at risk of treatment contrary to article 3, if returned. It would be interesting to see how a human rights body would deal with a claim from a humanitarian refugee who, although being under a real risk of their human rights being violated on return to their state of origin, was in no different situation from another national of the same state and the respondent state denied there would be a real risk of an article 3 violation on return. While the European Court of Human Rights may entertain such a claim, judging from the jurisprudence of the HRC so far it would appear that such a person could not satisfy their standard of proof. The response of the Court or Commission would be dependant on which approach they chose to follow. Although, taking account of the 1984 Cartagena Declaration and their use of such instruments to interpret the content of the ACHR and the ADRDM, it would appear that they would enforce the right of non-refoulement in such a circumstance. 


\title{
5.6. The Non-Derogability of Article 22(8) ACHR and article 27 ADRDM
}

The Court stated in its advisory opinion on Habeas Corpus in Emergency

Situations that

\begin{abstract}
'Article 27(2) must be interpreted in good faith, keeping in mind the object and purpose of ACHR and the need to prevent a conclusion that could give rise to the suppression of the enjoyment or exercise of the rights and freedoms recognised in ACHR or to restrict them to a greater extent than is provided for therein ${ }^{37}$.
\end{abstract}

It went on to add that

\begin{abstract}
'State Parties not only have the obligation to recognize and to respect the rights and freedoms of all persons, they also have the obligation to protect and ensure the exercise of such rights and freedoms by means of the respective guarantees, that is, through suitable measures that will in all circumstances ensure the effectiveness of these rights and freedoms. ${ }^{38}$.
\end{abstract}

It is suggested that the right of non-refoulement is such a guarantee against the violation of the rights and freedoms of all persons. Further, the right of non-refoulement is in an analogous position to that of judicial guarantees and, therefore, in that respect, non-derogable.

In its advisory opinion regarding Judicial Guarantees in States of Emergency $^{39}$, the Court accepted that even though the right of due process was not properly a 'judicial guarantee', it was necessary to enable the judicial guarantees to be effective within the context of article 27 . The reason that judicial guarantees are non-derogable is because they are essential to ensure 
the protection of non-derogable rights ${ }^{40}$. Non-refoulement is similarly essential; without it persons could be returned to states where there was a real risk that their non-derogable rights would be violated. Following this reasoning, the right of non-refoulement, specifically article 22(7) and (8) ACHR and article 27 ADRDM, should be non-derogable.

\section{Conclusion}

The principle of non-refoulement is the very foundation upon which all rights of refugees/asylum seekers stand. It is the gateway right that allows them access to all their other human rights within a state. Once a person is legally within the jurisdiction of a state, they are entitled to the full and free exercise of the rights and freedoms contained in the human rights instruments that state has ratified. This is what makes the norm of non-refoulement so crucial. It is, as the Commission has recognised, a fundamental human right. In this context therefore it is vital that the norm of non-refoulement is recognised as non-derogable and more than that, as a very part of the fundamental norms it protects: life, liberty and humane treatment. This paper has attempted to elucidate the different ways in which it can be shown that the norm of nonrefoulement is non-derogable. While it is relatively straightforward to prove that the right to non-refoulement contained within international agreements is non-derogable, it is more difficult to contend that the customary law norm of non-refoulement is non-derogable in and of itself. There is however no customary international law derogation clause and as such you can not derogate from a norm of international customary law. While a norm of 
customary international law may be inherently limited, due to the fact that its 'foundation' treaty provision is derogable, the customary international law norm of non-refoulement has no such limitation. In fact to the extent that the customary international law norm goes beyond the 1951 Convention definition, it is still non-derogable insofar as it is an integral part of the nonderogable rights it protects.

The norm of non-refoulement is akin to the right to due process of law. It is an ancillary right whose value is found not in the right itself but in the rights it seeks to protect. It has been shown that the norm of non-refoulement in both its human rights and refugee law elements is non-derogable through a variety of means. Although some of the lines of arguments overlap to the extent that they cover the same ground in a different way, they all have a different emphasis and can be used separately, in the alternative or concurrently, to add strength to the overall proposition. While states that have ratified the 1951 Convention are unable to derogate from it, states that have not, are still bound by it to the extent to which its precepts are customary norms. This means that no state can derogate from the fundamental norm of nonrefoulement. Additionally, it is important to emphasise that no OAS state can derogate from the customary right of non-refoulement in relation to those individuals who come within the refugee definition spelled out in the 1984 Cartagena Declaration. In relation to the human rights element of nonrefoulement, states cannot derogate from it to the extent that it is an inherent part of the fundamental right it protects. Further, it is submitted that article 22(7) and (8) ACHR and article 27 ADRDM are non-derogable both by virtue 
of the 1951 Convention and customary international law but also in connection with the fact that the rights contained in the articles are essential to ensure protection of the fundamental non-derogable rights contained in article 27(2) ACHR.

The Court has yet to pronounce on the scope, content and weight of the norm of non-refoulement within the Inter-American system. Until it does, the question to what extent the norm of non-refoulement is non-derogable within the Inter-American system will remain unanswered in any legally binding form. On the other hand, the Commission is becoming increasingly pro-active on matters relating to refugees/asylum seekers. In order to facilitate such a determination, an advisory opinion on the subject could be put before the Court or an individual petition, argued along one or more of the grounds outlined in the body of this article, brought before the Commission.

* Qualified Scots Solicitor, L.L.B. University of Glasgow (1996), Dip. L.P., University of Glasgow (1997).

${ }^{1}$ Report on Terrorism and Human Rights, para 375, OEA/Ser.L/V/II.116

${ }^{2}$ The DNS in the US has used immigration laws to do precisely that, see Request by the International Law Group, the Center for Constitutional Rights, and the Center for Justice and International Law, for Precautionary Measures under Article 25 of the Commission's Regulations, 20 June 2002. Text at http://www.hrlawgroup.org/resources/content/IACHRPrecautionaryMeasures.pdf

${ }^{3}$ Above n1

${ }^{4}$ OEA/Ser.L.V/II.82 doc.6 rev.1 at 25 (1992) 
${ }^{5} 1951$ Convention relating to the Status of Refugees, as amended by the Protocol relating to the Status of Refugees signed 31 ${ }^{\text {st }}$ January 1967 (1951 Convention), 187 UNTS 150, 606 UNTS 267.

${ }^{6}$ Above n1, para 50.

${ }^{7}$ Ibid, para 51

${ }^{8}$ Annex, 39 U.N. GAOR Supp. (No. 51) at 197, U.N. Doc. A/39/51 (1984)

${ }^{9}$ The Right to Information on Consular Assistance in the Framework of the Guarantees of the Due Process of Law, Advisory Opinion OC-16/99, October 1, 1999, Inter-Am. Ct. H.R. (Ser A) No. 16 (1999), para 115.

${ }^{10}$ There is a considerable amount of state practice of non-refoulement of 'humanitarian' refugees. See Hartman, 'The Principle and Practice of Temporary Refuge: A Customary Norm Protecting Civilians Fleeing Armed Conflict', The New Asylum Seekers: Refugee Law in the 1980s, D.A. Martin (ed), 1988, Dordrecht, M Nijhoff, p89.

${ }^{11}$ E. Lauterpacht \& D. Bethlehem 'The Scope and Content of the Principle of NonRefoulement: Opinion', Refugee Protection in International Law, E. Feller, V. Turk \& F. Nicholson (eds), 2003, Cambridge University Press, P87.

${ }^{12}$ Cartagena Declaration, para 2.

${ }^{13}$ Persons covered by the OAU Convention Governing the Specific Aspects of Refugee Problems in Africa and by the Cartagena Declaration on Refugees (Submitted by the African Group and the Latin American Group), para 47, U.N. Doc EC/1992/SCP/CRP.6. AG/res. 1971 (xxxiii-0/03)

The protection of refugees, returnees, and stateless and internally displaced persons in the Americas (Resolution adopted at the fourth plenary session, held on June 10, 2003), OAS AG/RES 1971 (XXXIII-0/03) The Protection Of Refugees, Returnees, And Stateless And Internally Displaced Persons In The Americas (Resolution adopted at the fourth plenary session, held on June 10, 2003)

${ }^{14}$ Mexico, Guatemala, Belize, Ecuador, Brazil, El Salvador, Peru and Paraguay - UNCHR 
${ }^{15}$ Soering v. United Kingdom, Application No. 14038/88 (1989), Chahal v. United Kingdom, Application No. 22414/93 (1996), Ahmed v. Austria 1997, Application No. 25964/94 (1996)

${ }^{16}$ Chitat Ng v. Canada, Communication No. 469/1991, U.N. Doc. CCPR/C/49/D/469/1991 (1994), Human Rights Committee, General Comment No. 20, U.N. Doc. HRI $\backslash$ GEN $\backslash 1 \backslash$ Rev.1 at 30 (1994)

${ }^{17}$ Soering $v . U K$, above $\mathrm{n} 15$, para 88

${ }^{18}$ Chahal v. UK, above n16, para 79, 80. Suresh v. Canada (Minister of Citizenship and Immigration) 2002 S.C.C. 1, para 72, 75, 126-130

${ }^{19}$ It should be noted that although the Commission has competency to hear individual petitions, it is only a quasi-judicial body and its decisions are not legally binding. Additionally, although ADRDM is not legally binding per se, it has become legally binding insofar as it defines the human rights duties laid upon member states of the OAS through the application of the OAS Charter. Interpretation of the American Declaration of the Rights and Duties of Man Within the Framework of Article 64 of the American Convention on Human Rights, Advisory Opinion OC-10/89, para 43, Inter-Am. Ct. H.R. (Ser. A) No.10. It is also binding through treaty and custom on all OAS member states. Report on Terrorism and Human Rights, Above n1, para 38

${ }^{20}$ Above n1, para 385

${ }^{21}$ In principle, according to the "fourth instance formula" the Commission cannot review judgments handed down by domestic courts within their competence and with due judicial guarantees, unless a possible violation of the American Convention has been committed. $X+Y$ v. Argentina, Case 11.676, Report No 71/00 (2000)

${ }^{22}$ Haitian Centre for Human Rights et al v. USA, Case No 10.675, Report No 51/96 (1997), para 155

${ }^{23}$ Interpretation of the American Declaration of the Rights and Duties of Man Within the Framework of Article 64 of the American Convention on Human Rights, Advisory Opinion, above n19, para. 37 and Villareal v. USA, Case 11.753, Report No 52/02 (2002), para 63 


\footnotetext{
${ }^{24}$ Above n22, para 170

2559 Stat. 1055

${ }^{26}$ Above 1, para 46 and Domingues v. USA, Case 12.285, Report No 62/02 (2002), para 45

${ }^{27}$ U.N. Doc. CCPR/C/21/Rev.1/Add.11 (2001)

${ }^{28}$ The same wording as in art $27 \mathrm{ACHR}$

${ }^{29}$ Art 4 ACHR contains a similar statement

${ }^{30}$ Above n16, para 9

${ }^{31}$ Mrs G.T. v Australia, Communication No. 706, U.N. Doc CCPR/C/61/D/706/1996, (1997), para 8.2

${ }^{32}$ Human Rights Committee, General Comment 31, Nature of the General Legal Obligation on States Parties to the Covenant, U.N. Doc. CCPR/C/21/Rev.1/Add.13 (2004)

${ }^{33}$ Haitian Centre for Human Rights case, above n22,

${ }^{34}$ R v. Secretary of State for the Home Department, ex parte Sivakuram 19981 All ER 193

${ }^{35}$ Above n18, para 99, 107

${ }^{36}$ Haitian Centre for Human Rights case, above n22, para 16. The Commission appears to have used a 'genuine and foreseeable consequence' test in this case.

${ }^{37}$ Habeas Corpus in Emergency Situations, para 16, (Arts. 27(2) and 7(6) of the American Convention on Human Rights), Advisory Opinion OC-8/87, (1987)

${ }^{38}$ Ibid, para 25

${ }^{39}$ Advisory Opinion OC-9/87 (1987)

${ }^{40}$ Above n37, para 27
} 